\title{
The Connection Between Ubuntu Indigenous Philosophy and the Gacaca Traditional Judicial Process in Rwanda
}

\author{
Samuel Hinton \\ Eastern Kentucky University, Richmond, USA
}

\begin{abstract}
This paper aims to discuss the connection between Ubuntu, a traditional humanistic philosophy, and Gacaca, an indigenous restorative justice process. The methodology used is narrative discourse. Th paper shares a background to the Rwanda genocide, defines Ubuntu and Gacaca respectively, and suggests a connection between the two. It concludes with a discussion on the global relevance of the Ubuntu-Gacaca paradigm to sustainable peace and reconciliation in a post-genocide society. The author advances a position that Ubuntu provided a springboard for the development of the Gacaca system of restorative justice as practiced in post-conflict Rwanda. The topic is significant because it will contribute to the literature of Ubuntu and Gacaca respectively. In addition, this Ubuntu-Gacaca paradigm has global implications for sustainable peace in post-conflict societies. Discussions on the Ubuntu-Gacaca paradigm should be continued. The model is amenable to adaptation and application in post-conflict areas around the world.
\end{abstract}

Keywords: Ubuntu, indigenous philosophy, Gacaca, traditional judicial process, Rwanda

\section{Introduction}

Internecine ethnic bickering combined with the legacy of Belgian colonialism (Republic of Rwanda, 2014) created a festering of animosity and hate in Rwanda over the years. This resulted in mass killings and victimization which later became known as the Rwanda genocide. Hauschildt (2012) stated that:

Over 100 days from April to July 1994 between 800,000 and 1,000,000 Tutsis and moderate Hutus were killed in Rwanda. The killings were organized by the Rwandan Government and executed by the military, armed militia groups and ordinary men and women who often killed their own relatives, friends, and neighbors (Corey \& Joiremann, 2004, p. 73; Clark \& Kaufman, 2008, p. 1). The Rwandan Patriotic Army (RPA), the military arm of the Rwanda Patriotic Front (RPF) which consisted of Tutsis living in Ugandan exile, defeated the Rwandan Government Forces and ended the genocide. (Graybill \& Lanegran, 2004, p. 8; Magnarella, 2005, p. 811)

At least 250,000 women were victims of sexual violence. Many of the women were subsequently killed and $70 \%$ of the survivors were infected with human immunodeficiency virus (HIV) (Amnesty International, 2004, p. 3; United Nations, Economic and Social Council, 1996). Half of the population was either internally displaced or had fled Rwanda. The country lost approximately $10 \%$ of its population and many of the survivors suffered from the traumatic experience. (Moghalu, 2005, p. 17)

The perpetrators and victims of the genocide continue to live together and therefore have to engage in a reconciliation process in order to avoid future violence. The challenge of reconciliation focuses on several interrelated issues and attention has to be paid to the suffering of individuals and of the nation as a whole (Richters, Dekkers, \& Jonge, 2005, p. 203). Moreover, the truth about past atrocities has to be established. It is very important that the basic human emotional needs of justice, empowerment, security, and recognition are met in order for the Rwandan society to move forward from

Samuel Hinton, Ph.D., professor, College of Education, Eastern Kentucky University. 
the genocide. (Shnabel \& Nadler, 2008, p. 116)

What is Ubuntu? According to Gade (2011), it is the moral quality of a person, or a phenomenon (for instance, a philosophy, an ethic, African humanism, or a worldview) according to which persons are interconnected. Foster (2006) stated that in the African worldview, human dignity is an essential element of Ubuntu. Dignity underlies true humanity, and in the African worldview, dignity is not just something that an individual creates for himseif/herself. Rather, true dignity is a reality created in common humanity. It is an interrelationship between self and other, and even the intangible reality of being a part of a living Kosmos (God, the ancestors, and the sacred harmony of the natural world).

Gade (2011) asserted that Ubuntu was connected with the proverb "Umuntu ngumuntu ngabantu" (People are people through people) during the period of 1993-1995. Most of the texts on Ubuntu published during the 2000s, either quoted the proverb or refered to the idea of the proverb that people are interconnected. As far as traditional African values are concerned, the fundamental importance of Ubuntu must be highlighted. Ubuntu, generally translated as "humanness", expresses itself metaphorically as "People are people through people" (Truth and Reconciliation Commission of South Africa, 1998).

Gade (2011) sketched a map of different ideas about the nature of Ubuntu found among South Africans of African descent. He hoped that other scholars will later join in on the project to make the map more detailed. The epilogue of South Africa's Interim Constitution (Truth and Reconciliation Commission of South Africa, 1998) stated that in addressing the divisions and strife of the past, there was "a need for understanding but not for vengeance, a need for reparation but not for retaliation, a need for Ubuntu but not for victimization". This constitutional reference to Ubuntu was followed by a significant increase in the number of texts published per year containing the term "Ubuntu".

There is a common dignity and all persons, in all creation, and, in fact, in all reality (both physical and spiritual), which creates the dignity of the individual. Intersubjectivity from an African perspective suggests, a person grows more fully human, more truly in their identity, through engagement with other persons. Shutte (2001) presented in his book Ubuntu: An Ethic for a New South Africa the following perspective:

A human person exists and develops as a person only in relation to other persons. The human self is not to be seen as something already formed and present in each human individual at birth. Instead, (the person) is still to be formed in the course of living. And it can only come into existence through the gift and influence of others. It is thus in no way material, something inside the body or the individual as for example, a mind-brain identity theorist might surmise. Insofar as it exists in a place it exists outside the body, in relation to other persons and the whole material environment. It is truer to the African idea, however, to see self and other as co-existing, each in the other in the sense of being identified with each other. The fundamental human reality must be seen as a field of personal energy in which each individual emerges as a distinct pole or focus. The field of life is the same in each; in each it is their humanity. All persons form a single person, not as parts for a whole, but as friends draw their life and character from the spirit of a common friend. They have a common identity.

Shnabel and Nadler (2008) suggested a needs-based model for satisfying the differential emotional needs of victim and perpetrator as a key to promoting reconciliation. Tutu (1999) suggested that Ubuntu aims at restoring the dignity of all people involved, and focusing on forgiveness in order to restore the "balance" between victim and perpetrator. In order to reconcile victim and perpetrator, justice may need to be restorative rather than retributive. Mandela (1994) interpreted Ubuntu through his experience during incarceration. He indicated that he had always known that deep down in every human heart, there is mercy and generosity. He 
believed that no one is born hating another person because of the color of his/her skin, his/her background, or his/her religion. He thought that people must learn to hate, because of that they can be taught to love, for love comes naturally to the human heart than the opposite. Even at the grimmest times in prison, when his colleagues and he were pushed to their limits, he would see a glimmer of humanity in one of the guards, perhaps just for a second, but it was enough to reassure him and keep him going. Man's goodness is a flame that can be hidden but not extinguished.

"Understanding conflict and developing appropriate models of handling it will necessarily be rooted in, and must respect and draw from, the cultural knowledge of a people" (Lederach, 1995, p. 10). Gacaca is a typical indigenous method of conflict resolution, resembling similar processes that developed over centuries throughout Africa, including the Mato Oput ${ }^{1}$ of Northern Uganda, the Gadaa system ${ }^{2}$ among the Oromo of Ethiopia (Oromiyaa, 2000), and the Guuirt ${ }^{3}$ of Somaliland. Gacaca is a distinctly Rwandan practice, although it has now been instrumentalized and infused with some Western ideas about justice. Gacaca is a Kinyarwanda concept which literally means "justice on the grass". Gacaca courts are a traditional Rwandese phenomenon, where people sit on the grass to settle their disputes in the presence of community members. In historical Rwanda, Gacaca courts were used to settle issues, such as land, property, marital, and other interpersonal disputes. Gacaca hearings are traditionally held outdoors and the system is based on voluntary confessions and apologies by wrongdoers.

According to Werchick (2003), in its pre-colonial form, Gacaca was used to moderate disputes concerning land use rights, cattle ownership, marriage, inheritance rights, and petty theft, among others. Traditionally, Gacaca courts were run by members of the community known as the inyangamugayo ${ }^{4}$ or "persons of exemplary conduct" who were renowned for courage, honor, justice, and truth. The inyangamugayo were special and were given this role based on their high moral and ethical standards. In traditional Rwanda, when the dispute has been resolved, this would be concluded by a ritual or ceremony, reflecting the symbolic and practical importance of the process. Gacaca sessions often ended with the parties sharing drinks and a meal as a gesture of reconciliation. Serious offences would result in the offender being ostracized from the community.

\section{Post-Conflict Reconstruction}

According to Karbo and Mutisi (2008):

Post-conflict reconstruction in Africa has been preoccupied with the hardware components, such as infrastructure development, rebuilding weakened institutions and facilitating socio-economic aspects of development, to the neglect of psychological (software) aspects of reconstruction. What is not in contestation is the idea that sustainable post-conflict reconstruction should happen at all levels including physical, economic, social and psychological. This is because violent conflict, especially of a virulent ethnic form like the genocide in Rwanda, destroys much more than buildings and roads. (p. 4)

\footnotetext{
${ }^{1}$ Mato Oput, the drinking of a bitter herb from the Oput tree is a detailed ceremony that is conducted during reconciliation among the Acholi of Northern Uganda. The resolution of the conflict is symbolized by conflicting parties drinking a bitter herb from the same pot.

${ }^{2}$ The Gadaa is a system of age grade classes that succeed each other in assuming political and social responsibilities. A complete Gadaa cycle consists of five age-grades. The authority held by the elders is derived from their position in the Gadaa system. For details, read Oromiyaa (2000).

3 The Guuirt is the highest level council of elders in Somaliland and the highest traditional authority. The council is headed by clan leaders or Sultans, and each council consists of a body of elders which represent the lineages in the clan.

4 "Inyangamugayo" is a Kinyarwanda word, which when literally translated means "people who hate evil". These are persons of integrity who are known to be uncorrupted, and they are appointed as judges in the Gacaca courts.
} 


\section{Psychology of Healing}

The psychological aspect of healing is imperative because those who have experienced the horrors of violent conflict are often scarred emotionally and left traumatized. In addition, healing at the psychological level allows for the rebuilding and mending of broken relationships, which is necessary for human society to remain intact. Scholars and practitioners contend that psychosocial healing is an effective way to reconstruct and rebuild society with an improved quality of life. The Gacaca process in Rwanda is a method of culturally sensitive approaches to psychological healing. Gacaca in Rwanda is a traditional mechanism of conflict resolution that attempts to address trauma and post-conflict reconstruction needs of that country's post-1994 genocide. The government of post-conflict Rwanda enacted the Gacaca Law (2001) to give indigenous courts the mandate to deal with cases of the genocide (Corey \& Joiremann, 2004, pp. 73-89). Thus, the Gacaca in Rwanda is one of the largest community-based judicial undertakings of the century. There are variant assertions over the role of Gacaca in promoting healing and post-conflict reconstruction. Proponents argue that endogenous methods like Gacaca courts in Rwanda represent a model of alternative or restorative justice, which are both cathartic and conciliatory.

The Rwandan genocide is one of the biggest wartime massacres which occurred in the 20th century. In April 1994, Rwanda was faced with horrific, massive, and brutal violence, where, over a period of three months, an estimated 800,000 Tutsis and moderate Hutus were killed, and two million fled the country. Against this background, the fundamental aspect of post-genocide Rwandan society and politics has been the need for reconciliation to mollify the ethnic tensions characterizing Rwandan society (Tiemessen, 2004). The Gacaca was reincarnated for both pragmatic and ideological reasons. From a practical standpoint, Rwanda's formal courts faced a backlog of over 120,000 prisoners, living in abject conditions, while the International Tribunal on Rwanda was also being swallowed by its huge case load. It was quite clear that the Rwandan formal legal system and the international criminal tribunal were not going to be able to deal with all these cases of genocide. The Gacaca was, therefore, a mechanism to decongest the country's prisons by speeding up trails at the community level. From an ideological viewpoint, Gacaca emphasizes the Rwandan government's need to promote culturally relevant approaches to reconciliation. Gacaca courts were resurrected in Rwanda as an indigenous form of restorative and transitional justice.

The Rwandan government passed a law creating Gacaca courts to prosecute crimes committed between October 1, 1990 and December 1, 1994. The government determined that it was critical to eradicate the culture of impunity in Rwanda, and to deter the possibility of another genocide. There was a need for justice, reconciliation, and nation-building in the post-genocide era. In addition, there was a need for a general definition of justice that would be reasonable to the vast majority of the population. The Gacaca system was first selected to help resolve issues of information gathering. Cases of persons accused of alleged crimes and incarcerated without evidence were handed over to the population in areas where the alleged crimes were committed for the purpose of gathering more information. In this pre-Gacaca period, those whose charges were not substantiated by evidence were set free provisionally, and those whose charges were backed by substantial evidence were recommended for continued detention and ultimate prosecution. The process was declared a success and the government turned the Gacaca into a regular feature in the judicial apparatus.

These courts ultimately became public tribunals, based on traditional Rwandan conflict resolution mechanisms organized for investigating crimes of genocide against the Rwandan people. The structure of the 
Gacaca courts was reorganized to fit current circumstances. Originally, the head of the court was a recognized community "sage". The purpose of deliberations was to resolve minor family and community disputes. The focus was not to punish offenders. That system provided a broad acceptance of the "justice" dispensed by the general population.

\section{Political Transition}

Many of the present ideas about the nature of Ubuntu, for instance, that Ubuntu is African humanism, a philosophy, an ethic, or a worldview, first emerged in written sources during the second half of the 1900s. Furthermore, Ubuntu became an object of particular interest and consideration during the political periods of transition from white minority rule to black majority rule in Zimbabwe and South Africa respectively (Gade, 2011, p. 30).

Julius Nyerere, first President of Tanzania, argued that Africans should adopt the philosophy of Ujaama, a traditional African form of socialism (Nyerere, 1966). He was convinced that after independence, a new historical phase of recovery had begun in Tanganyika. He described this phase of recovery as a revolution with a purpose of extending human dignity to all African citizens (Nyerere, 1966, p. 22).

Furthermore, Nyerere (1966) argued that the revolution could fulfil its purpose if society returned to its traditional socialism. This traditional socialism was to be reinvented as "Ujamaa" which, for Nyerere, represented a unique African kind of socialism that differed significantly from the European version: European socialism was born of the Agrarian Revolution and the Industrial Revolution which followed it. The former created the "landed" and the "landless" classes in society; the later produced the modern capitalist and the industrial proletariat. These two revolutions planted the seeds of conflict within society, and not only was European socialism born of that conflict, but its apostles sanctified the conflict itself into a philosophy. Civil war was no longer looked upon as something evil, or something unfortunate, but as something good and necessary. As prayer is to Christianity or to Islam, so civil war (which they called "class war") is to the European version of socialism - a means inseparable from the end (Nyerere, 1966, p. 169).

Nyerere (1966) stated that, a true African socialist does not consider one class of men as his/her brethren and another as his/her enemies. He/she does not form an alliance with the "brethren" for the extermination of the "non-brethren", but rather regards all human beings as members of an extended family. "Ujamaa", then, or "familyhood", describes socialism ("Ujamaa" is a Swahili word meaning "familyhood"). It is opposed to capitalism, which seeks to build a happy society on the basis of the exploitation of man by man; and it is equally opposed to doctrinaire socialism which seeks to build its happy society on a philosophy of inevitable conflict between man and man. He added that Africa, had no need to be converted to socialism or taught democracy because both are rooted in African traditional society (Nyerere, 1966, p. 170).

\section{Conclusion}

All human beings are all connected to a common humanity having the capability of doing good or evil. If people individually or collectively weigh the consequences of their actions, there will be less conflict and less suffering in the world. That kind of disposition will validate the human capacity to demonstrate compassion, reciprocity, dignity, and humanity, and to build and maintain positive community relations. Reciprocal respect and conversations about the essence of humanity between perpetrator and victim can help to prevent further violence. In contemporary Rwanda, during Gacaca processes, local residents give testimony for and against the suspects, who are usually tried in the communities where they are accused of committing crimes. 
The author stipulated that Ubuntu and Gacaca are connected. Ubuntu came into prominence during the liberation of Zimbabwe and South Africa respectively. Ubuntu stressed a need for understanding but not for vengeance, a need for reparation but not for retaliation, and a need for forgiveness but not for victimization. Gacaca stressed a need for restorative justice, not retributive justice, a need for forgiveness, not vengeance, a need for rehabilitation, not expulsion, a need for conversation, not agitation, a need for reconciliation, not division, and a need for sustainable peace, not protracted war. A Ubuntu-Gacaca model has global relevance to the achievement of sustainable peace and development in post-conflict societies.

\section{References}

Amnesty International. (2004). Rwanda: "Marked for Death", Rape survivors living with HIV/AIDS in Rwanda. Retrieved August 28, 2011, from http://www.amnesty.org/en/library/info/AFR47/007/2004

Clark, P., \& Kaufman, Z. (Eds.). (2008). After genocide: Transitional justice, post-conflict reconstruction and reconciliation in Rwanda and beyond. London, U.K.: Hurst.

Corey, A., \& Joiremann, S. (2004). Retributive justice: The Gacaca courts in Rwanda. African Affairs, 103, 73-89.

Foster, D. A. (2006). Validation of individual consciousness in strong artificial intelligence: An African theological contribution (Doctoral dissertation, University of South Africa).

Gade, C. B. N. (2011). The historical development of the written discourses on Ubuntu. South African Journal of Philosophy, 30(3), 303-329.

Graybill, L., \& Lanegran, K. (2004). Truth, justice, and reconciliation in Africa: Issues and cases. African Studies Quarterly, 8(1), 1-18. Retrieved November 6, 2010, from http://www.africa.ufl.edu/asq/v8/v8i1a1.pdf

Hauschildt, T. (2012). Gacaca courts and restorative justice in Rwanda. Retrieved August 9, 2014, from http://www.e-ir.info/

Karbo, T., \& Mutisi, M. (2008, October 2-4). Psychological aspects of post-conflict reconstruction: Transforming mindsets: The case of the Gacaca in Rwanda. Paper prepared for The Ad Hoc Expert Group Meeting on Lessons Learned in Post-Conflict State Capacity: Reconstructing Governance and Public Administration Capacities in Post-Conflict Societies Accra, Ghana.

Lederach, J. P. (1995). Preparing for peace: Conflict transformation across cultures. New York, N.Y.: Syracuse University Press.

Magnarella, P. (2005). The background and causes of the genocide in Rwanda. Journal of International Criminal Justice, 3(4), 801-822.

Mandela, N. (1994). A long walk to freedom: The autobiography of Nelson Mandela. Boston, M.A.: Little, Brown \& Company.

Moghalu, K. (2005). Rwanda's genocide: The politics of global justice. Basingstoke: Palgrave Macmillan.

Nyerere, J. K. (1966). Freedom and unity. Dar es Salaam: Oxford University Press.

Nyerere, J. K. (1968). Freedom and socialism. Dar es Salaam: Oxford University Press.

Oromiyaa, G. B. (2000). Understanding the Gadaa system. Retrieved from http://www.gumii.org/gada/understd.html

Republic of Rwanda. (2014). Colonial. Retrieved November 28, 2014, from http://www.gov.rw/colonial

Richters, A., Dekker, C., \& Jonge, K. (2005). Reconciliation in the aftermath of violent conflict in Rwanda. Intervention, 3, 203-221.

Shnabel, N., \& Nadler, A. (2008). A needs-based model of reconciliation: Satisfying the differential emotional needs of victim and perpetrator as a key to promoting reconciliation. Journal of Personality and Social Psychology, 94(1), 116-132.

Shutte, A. (2001). Ubuntu: An ethic for a new South Africa. Pietermaritzburg: Cluster Publications.

Tiemessen, A. (2004, March 17). Rwandan Gacaca: Competing and collaborating for justice after genocide. Paper presented at The Annual Meeting of the International Studies Association, Quebec, Canada. Retrieved August 7, 2014, from http://www. allacademic.com/meta/p74581_index.html

Truth and Reconciliation Commission of South Africa. (1998). Constitution of the Republic of South Africa, Act 200 of 1993 : Epilogue after Section 251.

Tutu, D. (1999). No future without forgiveness. London, U.K.: Rider.

United Nations Economics and Social Council. (1996). Report on the situation of human rights in Rwanda submitted by Mr. René Degni-Ségui, Special Rapporteur of the Commission of Human Rights. Retrieved March 17, 2012, from http://www.wfrt.org/ humanrts/commission/country51/7.htm

Werchick, L. (2003). Prospects for justice in Rwanda's citizen tribunals. Human Rights Brief, 8(3). Retrieved from http://www. wcl.american.edu/hrbrief/08/3rwanda/cfm 